\title{
Prognostic significance of DNA-binding capacity patterns in patients with lupus nephritis
}

\author{
MARK K. ADLER, ALEXANDER BAUMGARTEN, BARRY HECHT*, AND \\ NORMAN J. SIEGEL \\ From the Sections of Rheumatology and Nephrology, Departments of Internal Medicine and Pediatrics, \\ and the Department of Laboratory Medicine, Yale University School of Medicine, New Haven, Connecticut
}

\begin{abstract}
Adler, M. K., Baumgarten, A., Hecht, B., and Siegel, N. J. (1975). Annals of the Rheumatic Diseases, 34, 444-450. Prognostic significance of DNA-binding capacity patterns in patients with lupus nephritis. The time course of DNA binding capacity (DNA-bc) was found to correlate with the clinical course in a group of 21 patients who had biopsy-proven lupus glomerulonephritis and were treated with immunosuppressive agents. Eight patients showed a sequential DNA-bc pattern in which a high titre of anti-DNA antibody was present for a prolonged period of time all having an unfavourable clinical course. Persistently high values of DNA-bc preceded by as much as 10 months evidence of renal deterioration obtained by conventional renal function tests. Thirteen patients showed a low titre of anti-DNA antibody throughout most of their course, 12 having a favourable outcome. An initially high value of DNA-bc had no prognostic significance. These results suggest that the persistence of a high titre of anti-DNA antibody in patients with lupus glomerulonephritis is a poor prognostic sign.
\end{abstract}

A wide variety of antibodies reacting with nuclear and cytoplasmic antigens has been found in the serum of patients with systemic lupus erythematosus (SLE). There is, however, considerable evidence that the DNA/anti-DNA system is the most important of all recognized immune systems involved in the pathogenesis of lupus nephritis (Koffler and Kunkel, 1968; Cochrane and Koffler, 1973). Furthermore, a close correlation has been shown between high titres of anti-DNA antibody and clinically active renal disease (Casals, Friou, and Myers, 1964). In a long-term study of patients with lupus glomerulonephritis, those patients with persistently raised titres of anti-DNA antibody, which presumably reflects persistently active disease, would be expected to have a clinical course characterized by progressive renal impairment.

If this hypothesis is correct then serial determinations of anti-DNA antibody titres would be of prognostic significance, and it would be necessary to analyse serial anti-DNA antibody titres in a large group of patients with a similar renal lesion, treated with the same modality, but following two different clinical courses. Previous reports, however, either have studied heterogeneous groups in which random samples were correlated with clinical activity (Casals and others, 1964; Schur and Sandson, 1968) or have studied serial changes in a few patients correlating anti-DNA antibody titres with exacerbations and remission of disease (Hughes, Cohen, and Christian, 1971). The above hypothesis has therefore not yet been substantiated.

The present study correlates anti-DNA antibody titres, expressed as the DNA-binding capacity of serum (DNA-bc) with the long-term clinical course in 21 patients with proliferative lupus glomerulonephritis, treated with azathioprine and prednisone. It was also possible to determine whether DNA-bc titres provide a useful early index of disease activity.

\section{Materials and methods}

PATIENTS

Twenty-one patients between 8 and 34 years of age, followed by the Nephrology Section of the Department of Medicine and Pediatrics at Yale University School of Medicine, were available for study. All fulfilled the preliminary criteria for the classification of systemic lupus 
erythematosus as proposed by the American Rheumatism Association (Cohen, Reynolds, Franklin, Kulka, Ropes, Shulman, and Wallace, 1971). Each patient was treated with azathioprine (2-3 mg/kg per d) and prednisone in a dose (average range 10-20 mg/d) sufficient to control extrarenal manifestations of the disease.

At the time of initial evaluation and at intervals of at least 6 months during treatment the following investigations were made. Blood urea nitrogen (BUN), serum creatinine, total serum protein, albumin/globulin ratio, and quantitative protein excretion. The renal histopathological diagnosis in all patients was established at the time of initial evaluation by renal biopsy. All cases selected for this analysis showed a proliferative glomerulonephritis and subendothelial electron-dense deposits. At the time this study was completed, follow-up ranged from 13 months to 6 years, with a mean observation period of 36 months. At the end of follow-up patients were classified as having either a favourable or unfavourable clinical course. Patients were placed in the favourable category at end of follow-up if serum creatinine was $\leqslant 132.6 \mu \mathrm{mol} / 1$ $(1.5 \mathrm{mg} / 100 \mathrm{ml})$ and urinary protein excretion was reduced or stable. Patients were classified as having an unfavourable course when serum creatinine was $\geqslant 132.6 \mu \mathrm{mol} / 1$ $(\geqslant 1.5 \mathrm{mg} / 100 \mathrm{ml})$ and/or quantitative protein excretion increased by $1.0 \mathrm{~g} / \mathrm{d}$ or more.

Serum samples obtained from these patients at various intervals between 1968 and 1973 were analysed for DNA-bc. Sera stored at $-20^{\circ} \mathrm{C}$ was thawed overnight at $4^{\circ} \mathrm{C}$ before determination. Control samples were obtained from 100 healthy blood bank donors, 21 patients with seropositive rheumatoid arthritis, and 19 patients with rheumatoid variants, i.e., ankylosing spondylitis, Reiter's syndrome, and seronegative RA.

DNA-BINDING CAPACITY

DNA-bc was determined by the ammonium sulphate technique as modified by Pincus, Schur, Rose, Decker, and Talal (1969). Tritium-labelled $E$. coli DNA was kindly supplied by Dr. N. Rothfield (Luciano and Rothfield, 1973).

DNA-bc was determined by the addition of $0 \cdot 1 \mu \mathrm{g}$ DNA in $50 \mu \mathrm{l}$ borate sodium chloride buffer $(0.15 \mathrm{~mol} / 1, \mathrm{pH}$ $8.0)$ to $50 \mu \mathrm{l}$ of a $1: 10$ solution of unheated serum in the same buffer. The mixture was incubated for one hour at $37^{\circ} \mathrm{C}$ and then overnight at $4^{\circ} \mathrm{C}$. Saturated ammonium sulphate solution (SAS) $100 \mu \mathrm{l}$ was added while the mixture was vigorously agitated on a Vortex stirrer because inadequate mixing of the heavy SAS and less dense serum solution could cause marked variation of results in duplicate samples as previously noted by Farr (1958). The resulting $50 \%$ saturated mixture was maintained at $4{ }^{\circ} \mathrm{C}$ for one hour and then centrifuged at $12000 \mathrm{~g}$ for five minutes to sediment the precipitate. $100 \mu \mathrm{l}$ of the supernatant fraction (S) was then transferred to a liquid scintillation counting vial and $0.9 \mathrm{ml}$ distilled water added. The remaining $100 \mu \mathrm{l}(\mathrm{R})$ which contained both supernatant and precipitate was dissolved in $300 \mu$ l water and pooled with two $300 \mu \mathrm{l}$ washes of distilled water in a second counting vial. Phase Combining System liquid (PCS $8.5 \mathrm{ml}$ ) and $0.5 \mathrm{ml}$ NCS Solubilizer (AmershamSearle) were then added to each counting vial and the radioactivity of both $S$ and $R$ fractions determined in a liquid scintillation counter (Beckman). DNA-bc was cal- culated as a percentage of total radioactivity according to the formula: $100 \times(R-S) /(R+S)$.

Determinations on duplicate samples almost always agreed to $\pm 5 \%$ of their mean but the test was repeated when greater disparity occurred.

\section{Results}

DNA binding capacity for serum samples from normal controls, patients with rheumatoid arthritis, rheumatoid variants, and SLE is shown in Fig. 1. None of the samples obtained from patients with rheumatoid arthritis or rheumatoid variants exceeded a binding capacity of $20 \%$, although the means of the binding capacity for these groups were slightly higher than for normal controls. A binding capacity greater than $20 \%$, therefore, excluded not only healthy individuals but also patients with rheumatoid disease.

Although the majority of the serum samples from patients with SLE were obtained while they were in clinical remission and receiving immunosuppressive therapy, the mean binding capacity of all 257 samples was $38 \% \pm 31$ (SD). The mean binding capacity of the initial sera was, however, $62.5 \% \pm 37$ (SD), and was probably an underestimate because many of these patients had begun therapy before our initial serum sample.

Serial titres of DNA-bc were available in 21 patients for an average period of 36 months after the initiation of treatment. In order to determine whether DNA-bc levels correlated with the activity of the disease process, sequential titres were analysed and separated into two patterns based on either a high or low mean value of binding per patient during follow up. Type A (Fig. 2) was present in 14 patients and was charac-

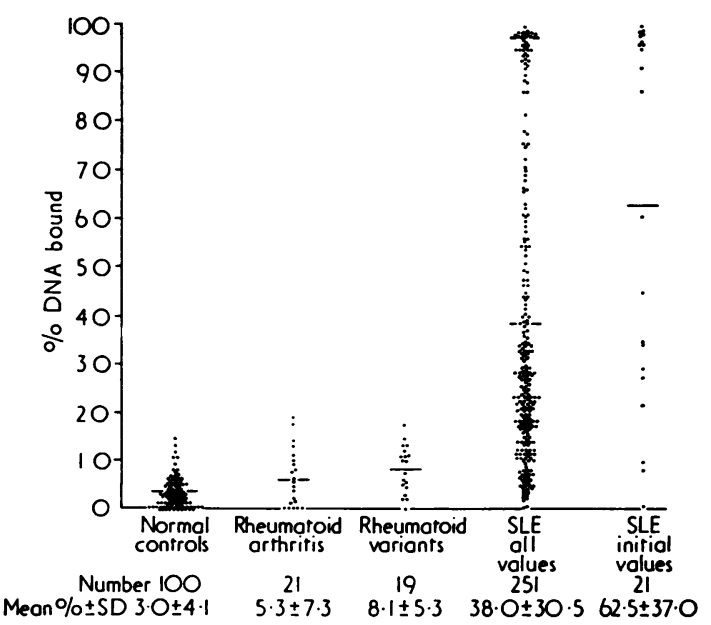

FIG. 1 DNA-binding capacity of sera from normal individuals and from patients with rheumatoid arthritis, rheumatoid variants, and SLE. Initial values and values for all 251 examined samples are shown 


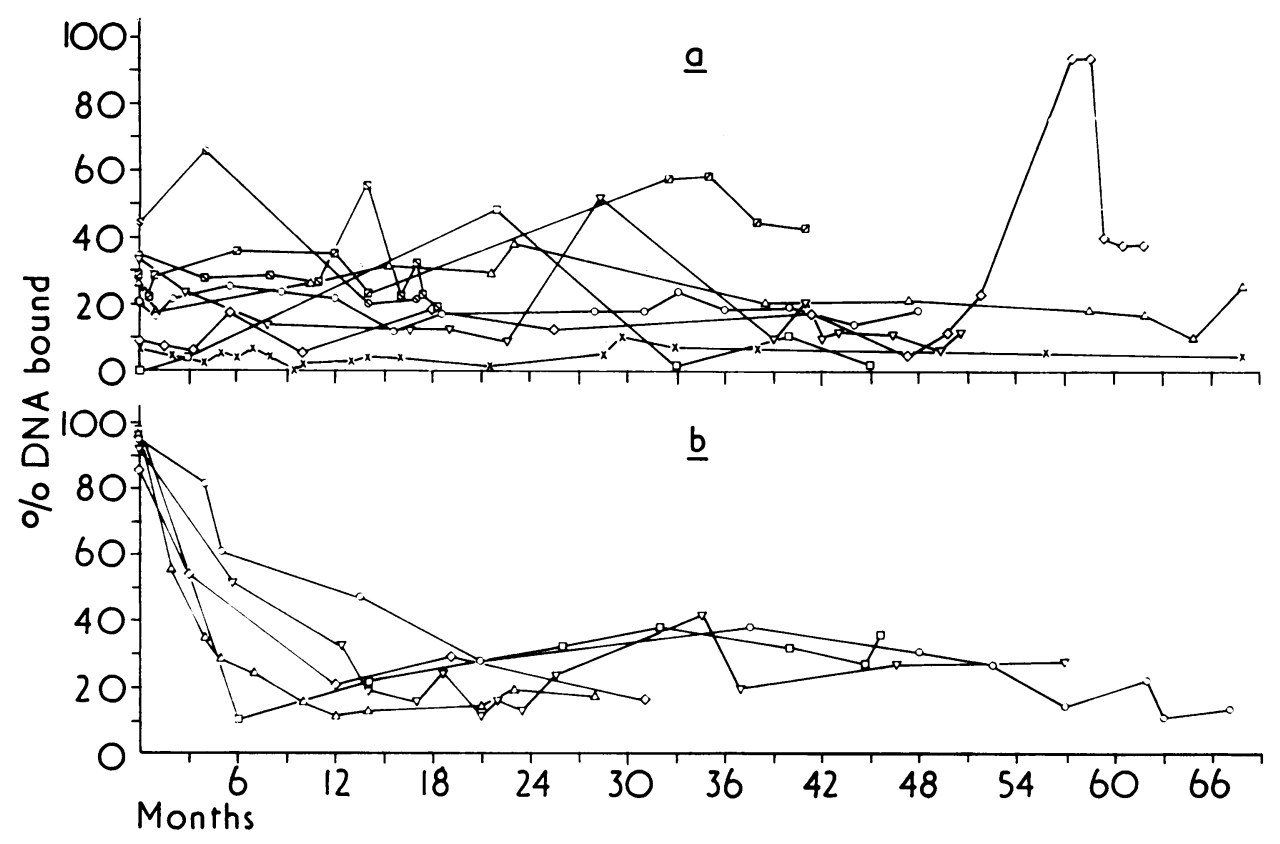

FIG. 2 Time course of DNA-binding capacity in 14 patients with SLE whose values were $60 \%$ or less throughout most of $\vec{\bullet}$ their documented course (group A). (a) The course of 9 patients in whom the initial values were low. (b) The course of 0 patients whose initial values were high but fell within 6 months of starting azathioprine therapy

terized by an average value of $40 \%$ or less during observation. In some cases in this group high initial values (Fig. $2 b$ ) rapidly fell below 40-60\% within 6 months of starting treatment, while in other patients (Fig. 2a) low levels persisted throughout follow up. Occasional transient increases above $40 \%$ usually corresponded to mild exacerbations of the systemic disease. In type B, found in 7 patients, sequential titres of DNA-bc averaged more than $60 \%$ (Fig. 3). In contrast to patients with type A pattern, DNA-bc levels in the group with type B were either consistently greater than $70 \%$ for 10 months or more after beginning treatment (Fig. $3 a$ ) or fluctuated widely with marked increases at frequent intervals (Fig. $3 b$ ). In all seven patients with type B pattern, DNA-bc fell to low levels in association with severe renal failure.

Correlations of the clinical course with the type of sequential DNA binding pattern is given in the Table. A favourable clinical outcome was found in 12 of 14 patients with a type A pattern. In each of these 12 cases renal function, as reflected by a serum creatinine value of $132.6 \mu \mathrm{mol} / 1(1.5 \mathrm{mg} / 100 \mathrm{ml})$, remained normal. Urinary protein excretion was reduced in nine patients and remained unchanged in three. In one patient (Case 21), despite a type A pattern, urinary protein excretion increased during treatment from $0 \cdot 1$ $\mathrm{g} / 24 \mathrm{~h}$ to $1.6 \mathrm{~g} / 24 \mathrm{~h}$ and this patient was classified as having an unfavourable clinical course. Another patient (Case 20), described in detail below, showed both types of DNA-bc patterns. This case is included in the group with an unfavourable clinical course because of the ultimate clinical outcome.

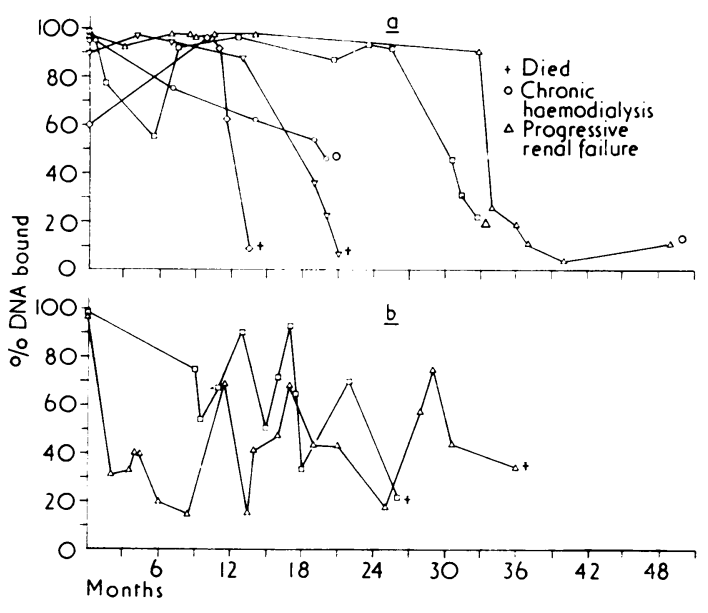

FIG. 3 Time course of DNA-binding capacity in 7 patients with SLE whose values were $70 \%$ or greater for at least 8 months (group B). (a) The course of 5 patients whose values were persistently high. (b) The course of 2 patients whose values fluctuated but were frequently high 


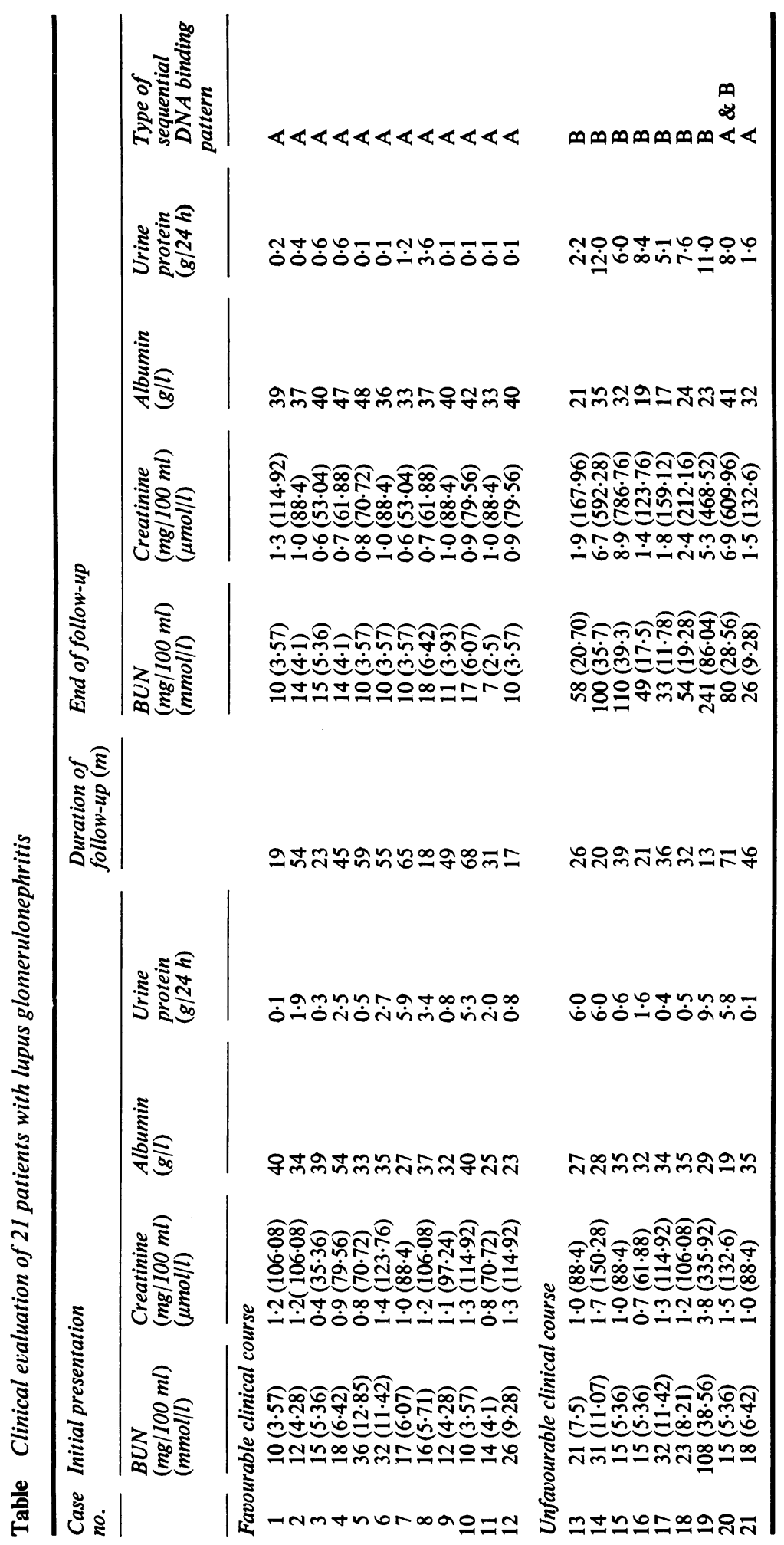


All seven patients with a type B pattern of sequential binding levels deteriorated. At the end of followup three patients had severe renal failure and of these, two were placed on chronic haemodialysis. The remaining four cases died during acute exacerbations of SLE from causes not related to renal failure.

For the purpose of comparison, the mean $\pm \mathrm{SE}$ of all values in patients with type $A$ and type $B$ binding patterns is shown in Fig. 4. In comparison with the sequential individual levels (Figs $2 \& 3$ ) it is apparent that the pattern of changes correlated better with the long-term clinical course than did values from single determinations.

In addition to the correlation between the clinical course of patients in this series and the pattern of sequential binding levels, changes in DNA-bc provided a useful index of variation in the disease process. All patients who had an unfavourable clinical course exhibited persistently raised DNA-bc levels for 4 to 10 months before conventional tests indicated failing renal function. This observation is exemplified by Case 20 who showed both type A and type B patterns.

Case 20, whose clinical course and serological parameters are shown in Fig. 5, presented at age 18 with fever, polyarthritis, and a positive LE cell preparation. Six months later, significant proteinuria, a serum creatinine of $132.6 \mu \mathrm{mol} / 1(1.5 \mathrm{mg} / 100 \mathrm{ml})$, low C3 value $(<0.6 \mathrm{~g} / \mathrm{l})$, and a high DNA-bc $(90 \%)$ were found. Renal biopsy showed diffuse proliferative lupus glomerulonephritis with mesangial and subendothelial deposits. The patient was started on prednisone and azathioprine. After 6 months on combined therapy, the DNA-bc had fallen to $30 \%$, while $\mathrm{C} 3 \mathrm{had}$ risen to $130 \mathrm{mg} / 100 \mathrm{ml}$. Both serological parameters remained at these levels for the subsequent 18 months. At 24 months, a repeat renal biopsy showed marked histological improvement with a

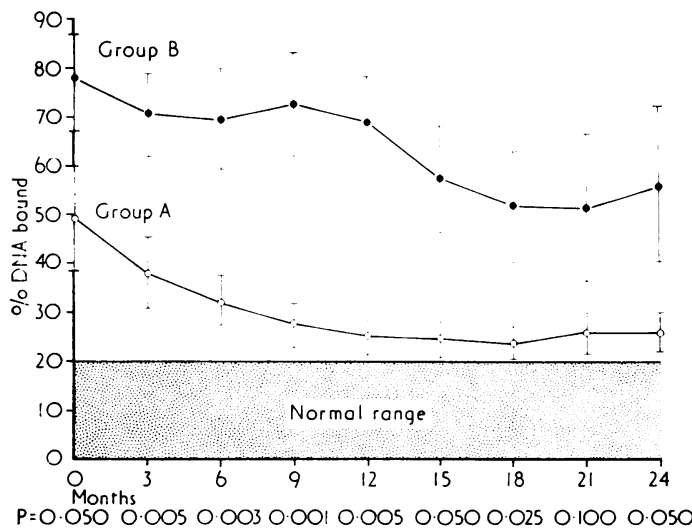

FIG. 4 Mean DNA-binding capacities and standard error for the 2 groups estimated at 3-monthly intervals. Two distinct patterns are seen
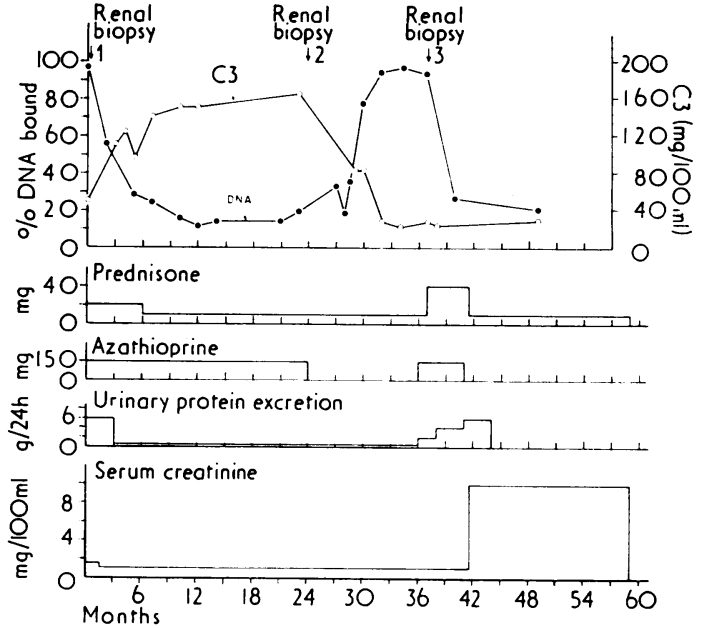

FIG. 5 Case 20. Course of a patient whose type A pattern changed after azathioprine was discontinued. DNA-binding capacity of the serum rose 6 months before there was clinical evidence of deterioration (see text). Conversion: Traditional to SI units-C3: $1 \mathrm{mg} / 100 \mathrm{ml} \simeq 0.01 \mathrm{~g} / 1$; serum creatinine: $1 \mathrm{mg} / 100 \mathrm{ml} \simeq 88.4 \mu \mathrm{mol} / 1$.

predominantly membranous pattern and subepithe lial and intramembranous deposits. To this point the DNA binding pattern was typical of type A, and correlated with marked clinical improvement. Az thioprine was then discontinued and the patient maintained on prednisone $10 \mathrm{mg} /$ day. Six months after discontinuing azathioprine, DNA-bc rose sharp- $\AA$ ly to $78 \%$ and remained raised for 8 months (type $\overrightarrow{\vec{O}}$ B), while C3 levels decreased and remained low. 3 However, it was not until 6 months after the rise in DNA-bc that the first clinical manifestations of active renal disease became apparent when proteinuria reappeared. A third renal biopsy showed a severe proliferative glomerulonephritis with massive $\frac{5}{3}$ subendothelial and mesangial deposits. DNA-bc levels fell at the time severe renal failure occurred.

\section{Discussion}

To examine the correlation between changes in levels $\frac{D}{3}$ of DNA antibody with the long-term course of patients with lupus nephropathy, serial changes in $\Omega$ DNA-bc were estimated in 21 patients with prolifera- N tive lupus glomerulonephritis during treatment with prednisone and azathioprine. This group of patients was of special interest since this renal histological

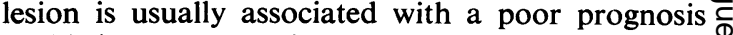
(Baldwin, Lowenstein, Rothfield, Gallow, and $\stackrel{\oplus}{\rightarrow}$ McClusky, 1970; Hayslett, Kashgarian, Cook, and 7 Spargo, 1972). In the present series approximately two-thirds of the patients improved while one-third deteriorated. It was therefore possible to analyse $\stackrel{\overparen{D}}{\circ}$ changes in DNA-bc in patients with a similar renal $\frac{\varrho}{0}$ 
lesion, treated with the same medications, following two different clinical courses.

The ammonium sulphate technique used in this study was shown to be a sensitive and specific method for the detection of antibodies to DNA (Pincus and others, 1969). DNA-bc values from normal controls and patients with rheumatoid disease in the present study were similar to those found by others (Pincus and others, 1969; Hughes, 1971).

Analysis of these data show that the initial determination of binding capacity does not always correlate with severity of renal injury. At the time of the initial renal biopsy levels less than $40 \%$ binding were found in 8 of 21 patients despite severe histological changes characterized by a proliferative glomerulonephritis and subendothelial deposits. Furthermore, the magnitude of the initial DNA-bc determination had no prognostic significance with regard to the final outcome. This seemed evident from the satisfactory progress of five patients whose initial DNA-bc exceeded $85 \%$ but decreased after starting therapy and remained low for 30 months or more (see Fig. $2 b$ ). Sequential measurements of DNA binding, however, revealed distinct patterns for patients exhibiting a favourable clinical course compared to patients who showed clinical deterioration. In twelve of thirteen patients with a stable or improved course by the end of follow-up, sequential binding levels persisted at a mean level of less than $40 \%$ or fell toward that range within 6 months of starting combined treatment (type A). In contrast, all eight patients with progressive clinical deterioration had a pattern characterized by raised mean values. Similar results have been obtained in NZB/NZW mice where a close correlation was found between the ability of a drug regimen to suppress titres of anti-DNA antibody and the progression of glomerulonephritis (Hahn, Bagby, Hamilton, and Osterland, 1973).

A persistently high DNA-bc level preceded the evidence of renal deterioration obtained by conventional renal function tests by as much as 10 months. Persistently raised DNA-bc may therefore indicate active disease which is not clinically apparent.
There was a sharp decline in binding capacity in six of eight patients with the onset of severe renal failure. Harbeck, Bardana, Kohler, and Carr (1973) noted a similar drop in DNA-bc in one patient when circulating immune complexes were present. Although this study did not examine the mechanism of this change, it is possible that release of large amounts of DNA bound the available circulating antibody. Whatever the explanation it is clear that under these circumstances low DNA-bc reflected severe exacerbation of disease rather than improvement. An accurate interpretation of these changes was only possible in light of the pre-existing pattern of DNA-bc.

The present study shows that the persistence and magnitude of anti-DNA antibody titres could be correlated with the clinical course in 21 patients with lupus nephropathy. The important implication derived from these data is that serial measurement of DNA-bc may serve as a useful guide in the management of lupus glomerulonephritis. As suggested by Epstein and Grausz (1974), it is probably the time of starting therapy rather than the use of a particular agent that favourably influences the prognosis. Therefore, in a patient with SLE and proliferative glomerulonephritis whose pattern of DNA-bc is known, it may be beneficial to modify treatment on the basis of serological parameters if significant changes persist for 3 consecutive months, such treatment being limited to patients with documented proliferative lupus glomerulonephritis only and not including all patients with SLE. It remains to be seen whether the addition of earlier and more aggressive therapy can prevent the development of the irreversible renal damage which occurred in several of our patients.

The authors express their appreciation to Dr. F. S. Kantor, who graciously provided sera from some of these patients, Dr. N. Rothfield for a gift of $\mathbf{H}^{3}$-labelled DNA, and to Drs. S. E. Malawista, J. P. Hayslett, and R. H. Gifford for invaluable guidance. Supported in part by grants from the USPHS (AM-10493, AM-5639) and from the Arthritis Foundation.

\section{References}

Baldwin, D. S., Lowenstein, J., Rothfield, N. F., Gallow, G., and McClusky, R. T. (1970) Ann. intern. Med., 73, 929 (The clinical course of the proliferative and membranous forms of lupus nephritis)

Casals, S. P., Friou, G. P., AND Myers, L. L. (1964) Arthr. and Rheum., 7, 379 (Significance of antibody to DNA systemic lupus erythematosus)

Cochrane, C. G., AND Koffler, D. (1973) Advan. Immunol. 16, 185 (Immune complex disease in experimental animals and man)

Cohen, A. S., Reynolds, W. E., Franklin, E. C., Kulka, P. J., Ropes, M. W., Shulman, L. E., and Wallace, S. E. (1971) Bull. rheum. Dis., 21, 643 (Preliminary criteria for the classification of systemic lupus erythematosus)

EPSTEIN, W. E., AND Grausz, H. (1974) Arthr. and Rheum., 17, 129 (Favorable outcome in diffuse proliferative glomerulonephritis of systemic lupus erythematosus)

FARR, R. S. (1958) J. Infect. Dis., 103, 239 (A quantitative immunochemical measure of the primary interaction between I BSA and antibody) 
HahN, B. H., Bagby, M. K., Hamilton, T. R., AND Osterland, K. C. (1973) Arthr. and Rheum., 16, 163 (Comparison of therapeutic and immunosuppressive effects of azathioprine, prednisone and combined therapy in NZB/NZW mice)

Harbeck, R. J., Bardana, E. J., Kohler, P. F., AND Carr, R. I. (1973) J. clin. Invest., 52, 789 (DNA anti-DNA complexes: Their detection in systemic lupus erythematosus sera)

Hayslett, J. P., Kashgarian, M., Cook, C. D., and Spargo, B. H. (1972) Medicine 51, 5 (The effect of azathioprine on lupus glomerulonephritis)

HuGHES, G. R. (1971) Lancet, 2, 861 (Significance of anti-DNA antibodies in systemic lupus erythematosus)

- Cohen, S. A., AND Christian, C. L. (1971) Ann. rheum. Dis., 30, 259 (Anti-DNA activity in systemic lupus erythematosus)

Koffler, D., AND KunKel, H. G. (1968) Amer. J. Med., 45, 165 (Mechanisms of renal injury in systemic lupus erythematosus)

-, Agnello, V., Thoburn, R., ANd Kunkel, H. G. (1971) J. exp. Med., 34, 1695 (Systemic lupus erythematosus: prototype of immune complex nephritis in man)

Luciano, A., AND Rothfield, N. F. (1973) Ann. rheum. Dis., 32, 337 (Patterns of nuclear fluorescence and DNA-binding activity)

Pincus, T., Schur, P. H., Rose, J. A., Decker, J. L., and Talal, N. (1969) New Engl. J. Med., 281, 701 (Measurement of serum DNA-binding activity in systemic lupus erythematosus)

Schur, P. H., AND SANDSON, J. (1968) New Engl.J. Med., 278, 533 (Immunologic factors and clinical activity in systemic lupus erythematosus) 